\title{
Lung volumes in giraffes, Giraffa camelopardalis
}

\author{
G. Mitchell ${ }^{\mathrm{a}, \mathrm{b}^{*}}$ and J.D. Skinner ${ }^{\mathrm{a}}$ \\ ${ }^{\text {a }}$ Centre for Veterinary Wildlife Studies, Faculty of Veterinary Science, University of Pretoria, South Africa \\ "Corresponding author. Dept 3166, 1000 E University Avenue, Dept of Zoology and Physiology, University of Wyoming, Laramie, WY 82071, \\ USA. Tel.: +1 36385129; fax: +1 363685129 . \\ ${ }^{\mathrm{b}}$ Dept of Zoology and Physiology University of Wyoming, USA
}

\begin{abstract}
We have measured lung mass and trachea dimensions in 46 giraffes of both genders ranging in body mass from $147 \mathrm{~kg}$ to $1441 \mathrm{~kg}$, calculated static and dynamic lung volumes, and developed allometric equations that relate changes in them to growth. We found that relative lung mass is $0.6 \pm 0.2 \%$ of body mass which is significantly less than it is in other mammals $(1.1 \pm 0.1 \%)$. Total lung volume is significantly smaller $\left(46.2 \pm 5.9 \mathrm{~mL} \mathrm{~kg}^{-1}\right)$ than in similar sized mammals $\left(75.0 \pm 2.1 \mathrm{~mL} \mathrm{~kg}^{-1}\right)$. The lung volume:body mass ratio decreases during growth rather than increase as it does in other mammals. Tracheal diameter is significantly narrower than in similar sized mammals but dead space volume $\left(2.9 \pm 0.5 \mathrm{~mL} \mathrm{~kg}^{-1}\right)$ is larger than in similar sized mammals $\left(2.4 \pm 0.1 \mathrm{~mL} \mathrm{~kg}^{-1}\right)$. Our calculations suggest that tidal volume $\left(10.5 \pm 0.2 \mathrm{~mL} \mathrm{~kg}^{-1}\right)$ is increased compared to that in other mammals $\left(10.0 \pm 0.2 \mathrm{~mL} \mathrm{~kg}^{-1}\right)$ so that the dead space:tidal volume ratio is the same as in other mammals. Calculated Functional Residual Capacity is smaller than predicted $\left(53.4 \pm 3.5\right.$ vs $\left.33.7 \pm 0.6 \mathrm{~mL} \mathrm{~kg}^{-1}\right)$ as is Expiratory Reserve Volume $\left(47.4 \pm 2.6\right.$ vs $27.2 \pm 1.0 \mathrm{~mL} \mathrm{~kg}^{-1}$, but Residual Volume $\left(6.0 \pm 0.4 \mathrm{~mL} \mathrm{~kg}^{-1}\right)$ is the same as in other similar sized mammals $\left(6.0 \pm 0.9 \mathrm{~mL} \mathrm{~kg}^{-1}\right.$. Our calculations suggest that Inspiratory Reserve Volume is significantly reduced in size (11.6 \pm 1.6 vs $\left.3.8 \pm 2.4 \mathrm{~mL} \mathrm{~kg}^{-1}\right)$, and, if so, the capacity to increase tidal volume is limited. Calculated dynamic lung volumes were the same as in similar sized mammals. We have concluded that giraffe morphology has resulted in lung volumes that are significantly different to that of similar sized mammals, but these changes do not compromise ventilatory capacity.
\end{abstract}

Keywords: Giraffes; Static lung volumes; Dynamic lung volumes

\section{Introduction}

The elongated shape of giraffes has produced relationships between structure and function that are different to those found in other mammals. This is true for the cardiovascular system (Mitchell and Skinner, 2009), the nervous system (Badlangana et al., 2007), and skeleton ([van Schalkwyk et al., 2004] and [van Sittert et al., in press]). The respiratory system also is adapted to their shape. A long neck requires a long trachea and a long trachea implies an enlarged respiratory dead space volume. The relatively small volume of the abdomino-thoracic cavity limits the space for lung expansion and/or for accommodating the digestive tract (Murie, 1872). The former complication was noticed first by Vosmaer (1787) during his reconstruction of a skeleton of a giraffe. He found that the "ribs formed a right angle with the spine and are rigid, incapable of being spread to facilitate respiration" (Vosmaer, 1787). Respiration, therefore, was 
achieved by the diaphragm and not accessory muscles. This conclusion was supported by the anatomical studies of (Joly and Lavocat, 1846) and (Cobbold, 1854). Cobbold later measured lung mass as an indicator of lung volume and in three animals found it to be between $0.56,0.82$, and $0.84 \%$ of body mass (Cobbold, 1860) whereas allometric predictions suggest that its relative mass should be greater than 1\% ([Tenney and Remmers, 1963] and [Stahl, 1967]). This small lung mass has been given as the reason for the supposed low exercise capacity of giraffes, most observations of which are anecdotal and historical ([Joly and Lavocat, 1846], [Harris, 1852] and [Lydekker, 1901], for example).

The first formal analysis of giraffe respiratory anatomy was made by Robin et al. (1960) who found that dead space volume was nine-times and total lung volume eight-times those in humans, and that the alveolar wall was thicker and lung elastic fibres more numerous and coarser than they were in humans. Robin et al. (1960) concluded that to overcome the large dead space the lungs were disproportionately larger and respiratory rate lower $(8-10 \mathrm{bpm})$ than expected for similar-sized animals. (Patterson et al., 1957) and (Patterson et al., 1965) compared giraffe and cow respiratory characteristics and also found a large dead space volume in giraffes $(2.6 \mathrm{~mL} / \mathrm{kg}$ vs $1.0 \mathrm{~mL} / \mathrm{kg}$ in cows), a lung mass of the expected $1 \%$ of body mass but a "surprisingly small lung volume", and a higher respiratory rate. Inspiration time was prolonged compared to cows (ca 2 to $3 \mathrm{~s}$ vs $0.9 \mathrm{~s}$ respectively), expiration time was similar (1.62 s vs $1.67 \mathrm{~s}$ ) and the average ratio of inspiration time to expiration time was 1.2 in giraffes and 0.6 in cows (Patterson et al., 1965). Conversely, Hugh-Jones et al. (1978) found that while giraffe dead space was ca $3 \mathrm{~mL} \mathrm{~kg}^{-1}$, it was 3.6 in deer (Cervus elephas), 3.1 in Llama (Lama glama) and 1.8 in camels (Camelus dromedarius), and thus was not unusually large. They concluded that giraffe compensated for a long neck by having a trachea that was narrower than expected (Hugh-Jones et al., 1978), with the consequence of greater resistance to airflow especially during exercise. The greater resistance explained the longer inspiratory time found by Patterson et al. (1965). Langman et al. (1982), who measured, but did not report, dead space volume also concluded that dead space was not abnormally large because the trachea, although long, was narrow. Thus no special compensation mechanisms were needed. However, Langman et al. (1982) concluded that resistance to airflow would be high and, therefore, increases in minute volume would be brought about by increased respiratory rate not tidal volume.

The contrary conclusions of (Robin et al., 1960), (Patterson et al., 1957) and (Patterson et al., 1965) on the one hand and those of (Hugh-Jones et al., 1978) and (Langman et al., 1982) on the other were based on studies of a total of 9 giraffes all young adults of a body mass of 500 $600 \mathrm{~kg}$. We report here the results of a study of the respiratory anatomy of 46 giraffes of a wide range of body weights. The purpose of the study was to quantify total lung volume and dead space volume in giraffes and describe how they change during growth. We have also quantified other giraffe static lung volumes, and dynamic lung volumes, and compared them to reported values for giraffes and to values that could be expected to be found in similar sized mammals in order to establish whether the respiratory system of giraffes is different to that of other mammals.

\section{Methods}

Direct measurement of static lung volumes has not been achieved so far in giraffes and is not feasible in animals generally: they cannot be persuaded to take the deep inspiratory and 
expiratory movements on command that are required to determine static lung volumes.

Estimating the approximate volumes in giraffes is more feasible and we have done this by measuring lung mass, tracheal dimensions, and body mass, and developed allometric equations for static and dynamic lung volumes so that "values found in giraffes can be compared with predicted figures at a given body mass with the goal of demonstrating physiological specialization" (Stahl, 1967). We also have compared our results with the few reported values for respiratory variables in giraffes.

Our data were obtained from 46 juvenile, young adult, and mature adult giraffes culled in Zimbabwe between April 2006 and April 2009. No institutional animal care approval was required for this study. Animals were culled according to the legal requirements of Zimbabwe. After the giraffes were shot the following measurements/calculations were made:

\subsection{Measured variables}

\subsubsection{Body mass $(\mathrm{Mb}, \mathrm{kg})$}

We used two methods to determine body mass to take into account loss of tissue during dissection and interseasonal variation. First, before any dissection took place we measured length and girth in metres and calculated body mass from regression equations developed for giraffes by Hall-Martin (1977). For giraffes these equations are:

Males: $26.117 * L^{*} G^{2}+33.945$

Females: $25.400 * L^{*} G^{2}+66.109$

Both: $25.902 * L^{*} G^{2}+45.758$

where $L$ is total length measured from the tip of the nose to the tip of the tail and $G$ the girth of the thorax measured immediately caudal to the front legs. Secondly, we weighed the giraffes piecemeal by weighing all body parts, including viscera and skin. The body mass of giraffes used in our analyses was the mean of the mass calculated from the relevant gender specific equations and the mass obtained from direct piecemeal weighing.

\subsubsection{Lung mass $\left(M_{\mathrm{L}}, \mathrm{kg}\right)$ and volume $\left(V_{\mathrm{L}}, \mathrm{L}\right)$}

$M_{\mathrm{L}}$ was found by weighing the lungs after removal of the conducting airways above the bifurcation of the trachea. $V_{\mathrm{L}}$ was calculated from the consistent allometric relationship between $M_{\mathrm{L}}$ and $V_{\mathrm{L}}$ of $6.6^{*} M_{\mathrm{L}}^{1.07}\left(\mathrm{~mL} \mathrm{~g}^{-1} ; R^{2}=.9992\right.$; Stahl, 1967) on the assumption that the general relationship between unit mass of lung tissue and unit volume is the same for giraffe lungs as it is for other mammals.

\subsubsection{Trachea dimensions and anatomical dead space volume (DS, L)}

Trachea dimensions needed to calculate DS were measured in situ to prevent distortion of the trachea by elastic recoil. DS, that volume of the lung that does not participate in gas exchange, was assumed to be equivalent to trachea volume ([Tenney and Bartlett, 1967] and [Calder, 
1996]). This assumption underestimates DS because the bronchial tree is extensive in giraffes (Nakakuki, 1983) and because, as in all mammals, it does not include physiological DS. Nevertheless, DS was calculated from trachea length and mean trachea diameter using the geometric formula for the volume of a cylinder. Trachea length $(\mathrm{cm})$ was measured from the first tracheal ring to its bifurcation into left and right bronchi ([Tenney and Bartlett, 1967] and [Nakakuki, 1983]). Trachea diameter $(\mathrm{cm})$ was measured at three points: at the first tracheal ring, at its midpoint, and just proximal to the bifurcation. Mean trachea diameter was calculated from these three measurements, and was used to calculate trachea cross-sectional area.

\subsection{Calculated variables}

\subsubsection{Tidal volume (TV, L)}

We calculated TV by adding to the expected TV for mammals of similar body mass (Stahl, 1967) the difference between predicted DS for mammals and the measured DS we found for giraffes.

\subsubsection{Vital capacity (VC, L)}

We assumed that the $\mathrm{VC}$ : VL ratio of giraffes is the same as that of other mammals and that VC therefore is described by the equation $1.06 * \mathrm{Mb}^{-.03}$ (Stahl, 1967).

\subsubsection{Functional residual capacity (FRC, L)}

We assumed that the FRC:VL ratio of giraffes is the same as that of other mammals and that FRC therefore is described by the equation $0.45 * \mathrm{Mb}^{.07}$ (Stahl, 1967).

\subsubsection{Remaining lung volumes}

No allometric relationships are known for any mammals other than humans for Inspiratory Reserve Volume (IRV, L), Expiratory Reserve Volume (ERV, L), or Residual Volume (RV, L). However from VL, TV, VC, and FRC these volumes can be calculated:

a) $\mathrm{IRV}=\mathrm{VL}-(\mathrm{TV}+\mathrm{FRC})$ with the additional dead space component of giraffe TV excluded

b) $\mathrm{RV}=\mathrm{VL}-\mathrm{VC}$, and

c) $\mathrm{ERV}=\mathrm{FRC}-\mathrm{RV}$

\subsubsection{Dynamic lung volumes}

Published data suggest that the respiratory rate of giraffes at rest scales with metabolic rate and follows typical mammalian patterns ([Robin et al., 1960], [Stahl, 1967], [Hugh-Jones et al., 1978], [Langman et al., 1982], [Worthington et al., 1991] and [Calder, 1996]). We used two allometric equations to estimate respiratory rate $(\mathrm{RR})$ - the general mammalian equation $\mathrm{RR}=51.2 * \mathrm{Mb}^{-.25}$ (Stahl, 1967) and one that included data from giraffes: $47.6 * \mathrm{Mb}^{-.24}$ (Worthington et al., 1991). There were no significant differences between the respiratory rates 
derived from these two equations. Minute ventilation $\left(V_{\mathrm{E}}, \mathrm{L} / \mathrm{min}\right)$ was $\mathrm{RR} * \mathrm{TV}$ and alveolar ventilation $\left(V_{\mathrm{A}}, \mathrm{L} / \mathrm{min}\right)$ was $\mathrm{RR} *(\mathrm{TV}-\mathrm{DS})$.

\subsection{Data analysis}

All data were entered into an Excel spreadsheet for analysis. As the relationship between body dimensions and organ dimensions is non-linear, data were log transformed for linear regression ([Prothero, 1979] and [Calder, 1996]) and the results used to develop allometric equations of the form $y=a^{*} \mathrm{Mb}$, where $a$ is the intercept, $M$ body mass in $\mathrm{kg}$, and $b$ the slope. When values for predicted and measured variables at specific body masses (i.e. $\mathrm{mL} \mathrm{kg}^{-1}$ ) were compared, differences were evaluated by paired, two tailed, $t$-test, assuming unequal variances. $P$ values $<0.05$ were regarded as significant.

\section{Results}

No significant differences were found between same-body mass males and females for any of the variables measured. Therefore, data were pooled.

\subsection{Body mass}

The range of body mass for the 46 giraffes was $147 \mathrm{~kg}$ in a juvenile female of 5 months of age to a $1441 \mathrm{~kg}$ mature male greater than 20 years old. Mean body mass of the group was $775 \mathrm{~kg}$. The correlation $\left(R^{2}\right)$ between piecemeal body mass and body mass calculated from length and girth was 0.9768 for males and 0.9786 for females.

\subsection{Lung mass $\left(M_{\mathrm{L}}\right)$ and lung volume $\left(V_{\mathrm{L}}\right)$}

The range of lung mass we found was $1.2-9.0 \mathrm{~kg}\left(0.6 \pm 0.1 \mathrm{~g} \cdot \mathrm{kg}^{-1}\right)$ and it was significantly lower than predicted mass of $1.6-15.2 \mathrm{~kg}\left(1.1 \pm 0.1 \mathrm{~g} . \mathrm{kg}^{-1} ; P<0.05\right)$ for animals of similar size. Consequently lung volume also was significantly smaller than predicted. Calculated lung volume of the giraffes in our sample ranged from 7.7 to $69.3 \mathrm{~L}\left(46.2 \pm 5.9 \mathrm{~mL} \mathrm{~kg}^{-1}\right)$ compared to a predicted range of 10-112 L $\left(75.0 \pm 2.1 \mathrm{~mL} \mathrm{~kg}^{-1}\right)$. The VL:Mb ratio decreased in giraffe as body mass increased whereas the predicted ratio increased as body mass increased (Fig. 1B; Table 3). 
A

Dead Space Volume

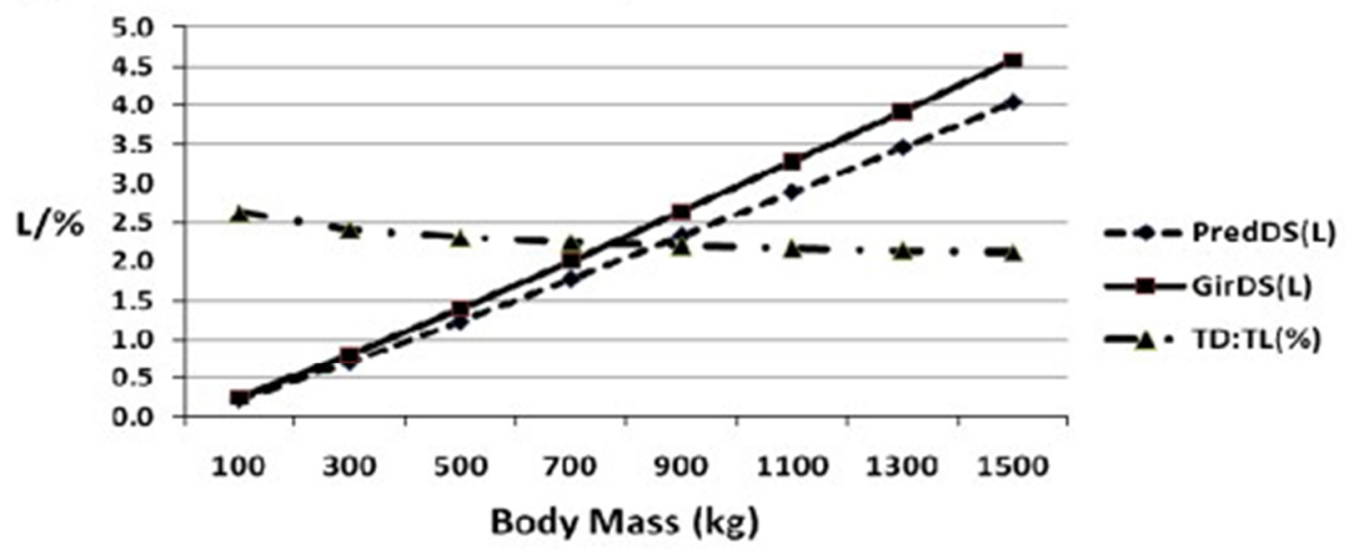

B

Lung Volume: Body Mass (VL:Mb)

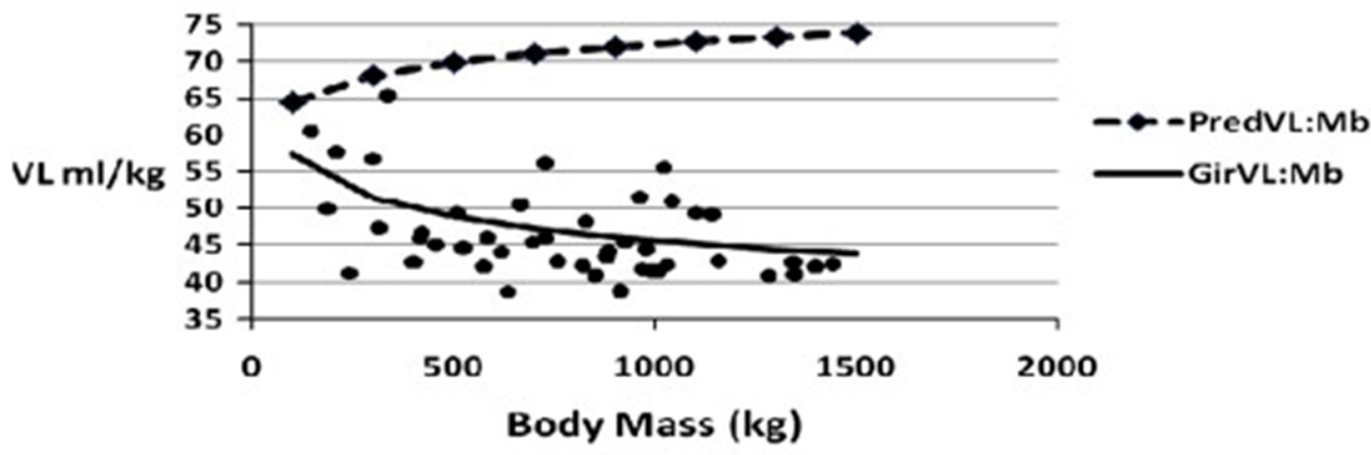

C Tidal Volume :Lung Volume (TV:VL)

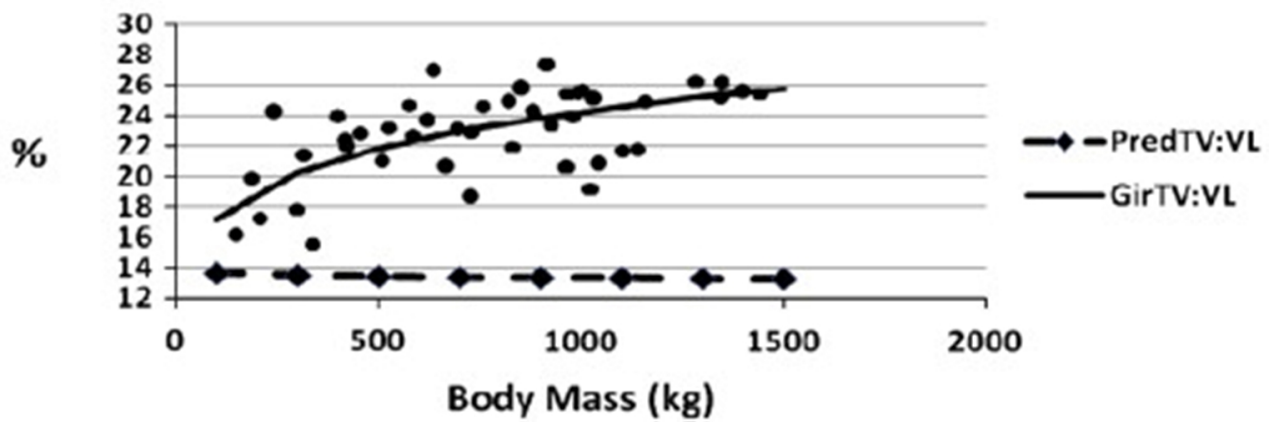

Fig. 1. The relationships between body mass and dead space volume (DS) and trachea diameter :length (TD:TL) ratio (A), lung volume to body mass ratio (VL:Mb; panel B), and tidal volume:lung volume ratio (TV:VL; panel C) in giraffes compared with predicted values. Filled circles in panels $\mathrm{B}$ and $\mathrm{C}$ show actual values. Note that in giraffes DS is larger than predicted and TD:TL decreases with growth. The VL:Mb ratio decreases in giraffes with growth whereas predicted values increase. Conversely, TV:VL ratio in giraffes increases with growth while predicted values show a constant ratio.

\subsection{Trachea dead space (DS) volume}

The range of DS was $0.4-4.2 \mathrm{~L}$ or $2.9 \pm 0.5 \mathrm{~mL} \mathrm{~kg}^{-1}$ (range 1.9-4.2 $\mathrm{mL} \mathrm{kg}^{-1}$ ) and was significantly larger in giraffes than predicted for similar sized mammals (range 0.4-3.7 L, or 
$2.4 \pm 0.1 \mathrm{~mL} \mathrm{~kg}^{-1}$, range $\left.2.1-2.5 \mathrm{~mL} \mathrm{~kg}^{-1} ; P<0.05\right)$ because of the length of the trachea (Table 1, Fig. 1). Tracheal diameter ranged from 2.3 to $4.8 \mathrm{~cm}$ and did not differ significantly between the cranial, middle, and caudal ends at any given body mass. Its diameter did not increase proportionately with increase in length, so with growth the trachea became relatively narrower and the ratio of diameter to length decreased (Fig. 1A). Trachea cross-sectional area increased almost three-fold during growth from $4.2 \mathrm{~cm}^{2}$ to $17.9 \mathrm{~cm}^{2}$ (Table 1).

Table 1. Measured lung volumes in a $775 \mathrm{~kg}$ giraffe and their ranges for 46 postnatal giraffes compared to predicted values for a typical mammal of the same body mass.

\begin{tabular}{|c|c|c|c|c|c|}
\hline Variable & $\begin{array}{l}775 \mathrm{~kg} \\
\text { Giraffe }\end{array}$ & $\begin{array}{l}\text { Range for } 147- \\
1441 \text { kg Giraffes }\end{array}$ & $\begin{array}{l}\text { Giraffe allometric } \\
\text { equations }\end{array}$ & $\begin{array}{l}775 \mathrm{~kg} \\
\text { Mammal }\end{array}$ & $\begin{array}{l}\text { Allometric equations } \\
\text { for predicted values }\end{array}$ \\
\hline \multirow[t]{2}{*}{ Lung mass (kg) } & 4.8 & $1.2-9.0$ & $.018 * \mathrm{Mb}^{.84}$ & 8.0 & $.011 * \mathrm{Mb}^{.99}$ \\
\hline & & & $R^{2}=.9264, P<.05$ & & \\
\hline \multirow[t]{2}{*}{$\begin{array}{l}\text { Lung } \\
\text { volume }(\mathrm{L})\end{array}$} & 36.3 & $7.7-69.3$ & $.091 * \mathrm{Mb}^{.90}$ & 61.9 & $.057 * \mathrm{Mb}^{1.05}$ \\
\hline & & & $R^{2}=.9264, P<.05$ & & \\
\hline \multirow[t]{2}{*}{$\begin{array}{l}\text { Trachea length } \\
\text { (m) }\end{array}$} & 1.75 & $0.8-2.5$ & $.10 * \mathrm{Mb}^{.43}$ & - & - \\
\hline & & & $R^{2}=.9701, P<.05$ & & \\
\hline \multirow[t]{2}{*}{$\begin{array}{l}\text { Trachea } \\
\text { diameter }(\mathrm{cm})\end{array}$} & 4.1 & $2.3-4.8$ & $.46 * \mathrm{Mb}^{.33}$ & 4.6 & $.35 * \mathrm{Mb}^{.39}$ \\
\hline & & & $R^{2}=.9201, P<.05$ & & \\
\hline \multirow[t]{2}{*}{$\begin{array}{l}\text { Trachea XS } \\
\text { area }\left(\mathrm{cm}^{2}\right)\end{array}$} & 12.1 & $4.2-17.9$ & $0.16 * \mathrm{Mb}^{.65}$ & 16.6 & $0.10 * \mathrm{Mb}^{.78}$ \\
\hline & & & $R^{2}=.9201, P<.05$ & & \\
\hline \multirow[t]{2}{*}{ Dead space (L) } & 2.24 & $0.4-4.2$ & $.0017 * \mathrm{Mb}^{1.08}$ & 1.85 & $.0014 * \mathrm{Mb}^{1.08}$ \\
\hline & & & $R^{2}=.9696, P<.05$ & & \\
\hline \multirow[t]{2}{*}{$\begin{array}{l}\text { Additional } \\
\text { DS (mL) }\end{array}$} & 381 & $59-709$ & $.27 * \mathrm{Mb}^{1.09}$ & - & - \\
\hline & & & $R^{2}=.9998, P<.05$ & & \\
\hline
\end{tabular}

${ }^{\mathrm{a}}$ From (Stahl, 1967), (Calder, 1981) and (Calder, 1996).

\subsection{Tidal volume}

The TV we calculated for our giraffes (range 1.4-15.8 L; $10.5 \pm 0.2 \mathrm{~mL} \mathrm{~kg}^{-1}$ ) was larger than predicted (range 1.4-14.8 L; mean $=10.0 \pm 0.2 \mathrm{~mL} \mathrm{~kg}^{-1}$ ) by an amount of about $400 \mathrm{~mL}$ per breath, because of the larger dead space (Table 1, Fig. 1A). The DS:TV ratio, however, was similar to the predicted value $(27.7 \pm 3.1 \%$ and $24.0 \pm 0.5 \%$ respectively; Table 3$)$. Conversely, 
because lung volume decreased relatively during growth, the TV:VL ratio increased from $c a$ $17 \%$ to $c a 26 \%$ (Fig. $1 \mathrm{C}$; Table 3 ). In mammals generally it is constant at ca $13 \%$ (Calder, 1981; Fig. 1C).

Table 3. Calculated ratios for lung variables in a $775 \mathrm{~kg}$ giraffe and their ranges for 46 postnatal giraffes compared to predicted values for a typical mammal of the same body mass.

\begin{tabular}{|l|l|l|l|l|l|}
\hline Ratio & $\begin{array}{l}\mathbf{7 7 5} \mathbf{~ k g} \\
\text { Giraffe }\end{array}$ & $\begin{array}{l}\text { Range for 147- } \\
\text { 1441 kg Giraffes }\end{array}$ & $\begin{array}{l}\text { Giraffe allometric } \\
\text { equations }\end{array}$ & $\begin{array}{l}\mathbf{7 7 5} \mathbf{~ k g} \\
\text { Mammal }\end{array}$ & $\begin{array}{l}\text { Allometric equations for } \\
\text { predicted values }^{\mathbf{a}}\end{array}$ \\
\hline DS:VL (\%) & 6.4 & $4.1-7.8$ & $1.82 * \mathrm{Mb}^{.19}$ & 3.3 & $2.66 * \mathrm{Mb}^{.03}$ \\
\hline & & & $R^{2}=.5180, P<.05$ & & \\
\hline DS:TV (\%) & 27.7 & $24.3-29.6$ & $21.2 * \mathrm{Mb}^{.04}$ & 24.3 & $18.6 * \mathrm{Mb}^{.04}$ \\
\hline & & & $R^{2}=.4503, P<.05$ & & \\
\hline TV:VL (\%) & 23.3 & $15.3-28.8$ & $8.6 * \mathrm{Mb}^{.15}$ & 13.4 & $14.3 * \mathrm{Mb}^{-.01}$ \\
\hline & & & $R^{2}=.6134, P<.05$ & & \\
\hline $\begin{array}{l}\text { VL:Mb } \\
(\mathrm{mL} / \mathrm{kg})\end{array}$ & 46.8 & $38.7-65.5$ & $91.0 * \mathrm{Mb}^{-.10}$ & 75.2 & $53.9 * \mathrm{Mb}^{.05}$ \\
\hline & & & $R^{2}=.4837, P<.05$ & & \\
\hline
\end{tabular}

${ }^{a}$ From (Stahl, 1967), (Calder, 1981) and (Calder, 1996).

\subsection{Other static lung volumes (Table 2)}

When we calculated other lung volumes inevitably the smaller lung volume resulted in proportionately smaller VC, FRC, IRV, ERV, and RV than predicted. The results are summarized in Table 2. When we related changes in these volumes during growth to changes in $\mathrm{Mb}$ we found that IRV decreased as $\mathrm{Mb}$ increased, VC, FRC, and ERV increased proportionally with increases in $\mathrm{Mb}$, while $\mathrm{RV}$ increased in size faster than increases in $\mathrm{Mb}$.

Table 2. Estimated lung volumes in a $775 \mathrm{~kg}$ giraffe and their ranges for 46 postnatal giraffes compared to predicted values for a typical mammal of the same body mass.

\begin{tabular}{|l|l|l|l|l|l|}
\hline Variable & $\begin{array}{l}\mathbf{7 7 5} \mathbf{~ k g} \\
\text { Giraffe }\end{array}$ & $\begin{array}{l}\text { Range for 147- } \\
\mathbf{1 4 4 1} \mathbf{k g} \text { Giraffes }\end{array}$ & $\begin{array}{l}\text { Giraffe allometric } \\
\text { equations }\end{array}$ & $\begin{array}{l}\mathbf{7 7 5} \mathbf{~ k g} \\
\text { Mammal }\end{array}$ & $\begin{array}{l}\text { Allometric equations } \\
\text { for predicted values }\end{array}$ \\
\hline Tidal volume (L) & 8.18 & $1.5-15.0$ & $.0081 * \mathrm{Mb}^{1.04}$ & 7.79 & $.0077 * \mathrm{Mb}^{1.04}$ \\
\hline & & & $R^{2}=.9973, P<.05$ & & \\
\hline Vital capacity (L) & 30.5 & $8.1-52.1$ & $0.1 * \mathrm{Mb}^{.86}$ & 53.9 & $.057 * \mathrm{Mb}^{1.03}$ \\
\hline & & & $R^{2}=.9772, P<.05$ & & \\
\hline $\begin{array}{l}\text { Functional } \\
\text { residual capacity } \\
\text { (L) }\end{array}$ & 26.0 & $5.2-47.5$ & $.041 * \mathrm{Mb}^{.97}$ & 43.1 & $.024 * \mathrm{Mb}^{1.12}$ \\
\hline
\end{tabular}




\begin{tabular}{|c|c|c|c|c|c|}
\hline Variable & $\begin{array}{l}775 \mathrm{~kg} \\
\text { Giraffe }\end{array}$ & $\begin{array}{l}\text { Range for } 147- \\
1441 \text { kg Giraffes }\end{array}$ & $\begin{array}{l}\text { Giraffe allometric } \\
\text { equations }\end{array}$ & $\begin{array}{l}775 \mathrm{~kg} \\
\text { Mammal }\end{array}$ & $\begin{array}{l}\text { Allometric equations } \\
\text { for predicted values }\end{array}$ \\
\hline & & & $R^{2}=.9816, P<.05$ & & \\
\hline \multirow{2}{*}{$\begin{array}{l}\text { Inspiratory } \\
\text { reserve volume } \\
\text { (L) }\end{array}$} & 2.1 & $0.3-4.9$ & $3.6 * \mathrm{Mb}^{-.08}$ & 9.6 & $.050 * \mathrm{Mb}^{.79}$ \\
\hline & & & $R^{2}=.2106, P>.05$ & & \\
\hline \multirow{2}{*}{$\begin{array}{l}\text { Expiratory } \\
\text { reserve volume } \\
\text { (L) }\end{array}$} & 20.8 & $4.4-37.4$ & $.040 * \mathrm{Mb}^{.94}$ & 36.2 & $.024 * \mathrm{Mb}^{1.10}$ \\
\hline & & & $R^{2}=1.0, P<.05$ & & \\
\hline \multirow[t]{2}{*}{$\begin{array}{l}\text { Residual volume } \\
\text { (L) }\end{array}$} & 4.6 & $0.7-9.4$ & $.0027 * \mathrm{Mb}^{1.12}$ & 8.0 & $.0016 * \mathrm{Mb}^{1.28}$ \\
\hline & & & $R^{2}=.9998, P<.05$ & & \\
\hline \multirow[t]{2}{*}{$\begin{array}{l}\text { Minute } \\
\text { ventilation } \\
(\mathrm{L} / \mathrm{min})\end{array}$} & 79.9 & $25.4-125.5$ & $.39 * \mathrm{Mb}^{80}$ & 74.8 & $.39 * \mathrm{Mb}^{.79}$ \\
\hline & & & $R^{2}=1.0, P<.05$ & & \\
\hline \multirow{2}{*}{$\begin{array}{l}\text { Alveolar } \\
\text { ventilation } \\
(\mathrm{L} / \mathrm{min})\end{array}$} & 57.4 & $15.1-98.9$ & $.32 * \mathrm{Mb}^{.78}$ & 59.1 & $.27 * \mathrm{Mb}^{.81}$ \\
\hline & & & $R^{2}=.9800, P<.05$ & & \\
\hline
\end{tabular}

${ }^{\mathrm{a}}$ From (Stahl, 1967), (Calder, 1981) and (Calder, 1996).

\subsection{Dynamic lung volumes}

We found that both giraffe $V_{\mathrm{E}}$ (range $21.6-129.3 \mathrm{~L} / \mathrm{min}$; mean $=105.2 \pm 12.7 \mathrm{~mL} \mathrm{~kg}^{-1} \mathrm{~min}^{-1}$ ) and their $V_{\mathrm{A}}$ (range 15.1-98.9 L/min; $75.9 \pm 11.1 \mathrm{~mL} \mathrm{~kg}^{-1} \mathrm{~min}^{-1}$ ) were the same as predicted for mammals of similar body mass $\left(V_{\mathrm{E}}\right.$ range $=20.5-127.5 \mathrm{~L} / \mathrm{min}$;

mean $\left.=102.3 \pm 12.5 \mathrm{~mL} \mathrm{~kg}^{-1} \mathrm{~min}^{-1} ; V_{\mathrm{A}}=15.4-98.7 \mathrm{~L} / \mathrm{min} ; 79.4 \pm 8.8 \mathrm{~mL} \mathrm{~kg}^{-1} \mathrm{~min}^{-1}\right)$.

Overall our analyses suggest that arising from a smaller total lung volume the absolute size of each volume or capacity is smaller than expected with the exception of dead space, tidal volume, and FRC, which are larger. The most noticeable difference was IRV, which was approximately $25 \%$ of what it is in similar sized mammals. Nevertheless, dynamic lung volumes were the same as those predicted for mammals of similar body mass. 


\section{Discussion}

A main function of the lung is to facilitate gas exchange by diffusion: the larger the animal the greater the diffusing surface needed (Hoppeler and Weibel, 1998). Thus in almost all mammals as body mass increases lung volume also increases ([Tenney and Remmers, 1963] and [Stahl, 1967]). Our data suggest that this general principle does not apply to giraffes. Giraffe lung volume is significantly smaller than predicted for mammals of similar body mass and it decreases relative to increases in body mass. This finding confirms what has been suspected since the first studies of giraffe respiratory anatomy ([Vosmaer, 1787], [Joly and Lavocat, 1846], [Murie, 1872], [Cobbold, 1854] and [Cobbold, 1860]) and it is supported by more recent measurements made by Gehr et al. (1981). Gehr et al. (1981) measured lung volume in a giraffe by volume displacement. Applying the equation derived by Gehr et al. (1981) to our giraffes, mean $V_{\mathrm{L}}$ in our giraffes was calculated to be $41.8 \pm 18.2 \mathrm{~L}$ compared to the $34.9 \pm 14.8 \mathrm{~L}$ we found from measurements of lung mass. This difference was not significant $(P>0.05)$ and the finding suggests that lung volume in giraffes can be determined from lung mass. The small size of the lungs probably is related to the small abdomino-thoracic cavity (Murie, 1872) arising from the adjustments to skeletal morphology needed to support the neck (van Sittert et al., 2010). The reduction in space without a parallel reduction in volume of the digestive system must have the effect that digestive organs occupy thoracic space and so limit lung volume. The consequence of the small total lung volume is that component volumes and capacities similarly are reduced ([Table 1] and [Table 2]; Fig. 1) and a reasonable conclusion is that diffusion area for oxygen will be smaller and oxygen delivery to tissues compromised.

Some evidence that supports this conclusion is that $\mathrm{VO}_{2 \max }$ in giraffes is relatively low $\left(32.3 \pm 3.4 \mathrm{~mL} / \mathrm{kg} \mathrm{min}{ }^{-1}\right.$; [Taylor et al., 1980], [Gehr et al., 1981] and [Taylor et al., 1987]; Table 2) compared to, say, wildebeest (Connochaetes gnou; $43 \mathrm{~mL} / \mathrm{kg} \mathrm{min}^{-1}$ ) and Eland (Taurotragus oryx; $36 \mathrm{~mL} / \mathrm{kg} \mathrm{min}^{-1}$ ) (Weibel et al., 2004). The low $\mathrm{VO}_{2 \max }$ is not a result of abnormal haematology: arterial and venous blood gas concentrations, haematocrit and haemoglobin concentration are similar in giraffes to those in other mammals ([Drevemo et al., 1974], [Hawkey, 1975] and [Bush et al., 1980]). Theoretically, $\mathrm{VO}_{2 \max }$ is reached at the relatively low running speed of $18.7 \pm 1.2 \mathrm{~km} / \mathrm{h}$ (Taylor et al., 1980; Table 2), which classifies giraffe as a non-athletic species (Weibel et al., 2004). This physiological conclusion supports historical observations but is contrary to more recent observations of giraffe athletic performance. For example Dagg and Foster (1976) have reported that giraffes can outrun most horses and can set up a steady pace which they can continue for several hours. Langman et al. (1982) reported that giraffes can run at $65 \mathrm{~km} / \mathrm{h}$ for $5 \mathrm{~min}$. Lung and capillary surface areas are large amounting to $1.5 \pm 0.1 \mathrm{~m}^{2} \mathrm{~kg}^{-1}$ and $1.4 \pm 0.1 \mathrm{~m}^{2} \mathrm{~kg}^{-1}$ respectively, or $c a 1200 \mathrm{~m}^{2}$ each in a $775 \mathrm{~kg}$ giraffe (Table 4). Diffusion capacity (ca1000 L min ${ }^{-1}$ in a $775 \mathrm{~kg}$ giraffe) and the thickness of the diffusion barrier are not different to that of other mammals (Gehr et al., 1981; Table 4). Mass specific oxygen consumption (metabolic rate) reported in the two studies that have measured it, is $2.6 \mathrm{~mL} / \mathrm{kg} \mathrm{min}^{-1}$ in 500-600 kg giraffes ([Patterson et al., 1965] and [Langman et al., 1982]). Our equations predict BMR of 2.3-2.9 mL/kg min ${ }^{-1}$ for animals of that size (Table 4). Field metabolic rate (FMR) is about twice as high as BMR ([Calder, 1996] and [Nagy, 2005]). From our estimates of $V_{\mathrm{A}}$ and assuming a typical alveolar oxygen concentration of $14 \%$, oxygen delivery to the lungs exceeds BMR by on average $5.2 \pm 0.3$ fold and FMR by $2.2 \pm 0.1$ fold respectively. In addition diffusion capacity increases with $\mathrm{VO}_{2 \max }$ to the power of 
1.27 in giraffes (Gehr et al., 1981), and their respiratory system is sensitive to changes in oxygen demand. It responds by increasing respiratory rate rather than tidal volume (Langman et al., 1982), a change that is mediated by a carotid body (Patterson et al., 1957). In other words despite a small lung, oxygen provision by the respiratory system at rest always is more than enough and can be adjusted upwards during exercise by a combination of increased respiratory rate and diffusing capacity. These observations are consistent with the idea that the lungs of mammals have evolved to provide excess capacity so that organisms can evolve despite adverse environmental conditions or anatomical constraints (Hoppeler and Weibel, 1998). They are also consistent with the fact that oxygen consumption is determined more by the oxidative capacity of tissues than by the capacity of the lung for gas exchange ([Taylor et al., 1980], [Hoppeler and Weibel, 1998] and [Weibel et al., 2004]).

Table 4. Predicted metabolic characteristics of a $775 \mathrm{~kg}$ giraffe and predicted mean $\pm \mathrm{sd}$ for the 46 postnatal giraffes in this study.

\begin{tabular}{|l|l|l|l|l|}
\hline Variable & $\begin{array}{l}775 \mathbf{~ k g} \\
\text { Giraffe }\end{array}$ & Mean \pm sd & $\begin{array}{l}\text { Allometric } \\
\text { equation }\end{array}$ & Reference \\
\hline Body mass $(\mathrm{kg})$ & 775 & $147-1441$ & - & This study \\
\hline Basal $\mathrm{VO}_{2}\left(\mathrm{~mL} / \mathrm{kg} \mathrm{min}^{-1}\right)$ & 2.1 & $2.2 \pm 0.3$ & $9.7 * \mathrm{Mb}^{-.23}$ & $\begin{array}{l}\text { (Stahl, 1967), (Hayssen and Lacy, } \\
\text { 1988) and (Schmidt-Nielsen, 1997). }\end{array}$ \\
\hline Field $\mathrm{VO}_{2}\left(\mathrm{~mL} / \mathrm{kg} \mathrm{min}^{-1}\right)$ & 6.5 & $5.3 \pm 0.9$ & $30.0 * \mathrm{Mb}^{-.23}$ & (Calder, 1996) and (Nagy, 2005) \\
\hline $\mathrm{VO}_{2 \mathrm{max}}\left(\mathrm{mL} / \mathrm{kg} \mathrm{min}^{-1}\right)$ & 31.0 & $32.3 \pm 3.4$ & $102.8 * \mathrm{Mb}^{-.18}$ & $\begin{array}{l}\text { (Gehr et al., 1981), (Calder, 1996) } \\
\text { and (Weibel et al., 2004). }\end{array}$ \\
\hline $\begin{array}{l}\text { Running speed at } \mathrm{VO}_{2 \mathrm{max}} \\
(\mathrm{km} / \mathrm{h})\end{array}$ & 18.9 & $18.7 \pm 1.2$ & $8.4 * \mathrm{Mb}^{.122}$ & Taylor et al. (1980) \\
\hline Alveolar surface Area $\left(\mathrm{m}^{2}\right)$ & 1174.9 & $1159.5 \pm 461.8$ & $3.6 * \mathrm{Mb}^{.87}$ & Gehr et al. (1981) \\
\hline $\begin{array}{l}\text { Alveolar surface Area } \\
\left(\mathrm{m}^{2} / \mathrm{kg}\right)\end{array}$ & 1.52 & $1.55 \pm 0.12$ & $3.6 * \mathrm{Mb}^{-.13}$ & $"$ \\
\hline $\begin{array}{l}\text { Pulmonary Capillary } \\
\text { surface Area (m }\end{array}$ & 1046.4 & $1033.6 \pm 415.5$ & $3.0 * \mathrm{Mb}^{.88}$ & $"$ \\
\hline $\begin{array}{l}\text { Pulmonary capillary } \\
\text { surface area }\left(\mathrm{m}^{2} / \mathrm{kg}\right)\end{array}$ & 1.35 & $1.37 \pm 0.10$ & $3.0 * \mathrm{Mb}^{-.12}$ & $"$ \\
\hline $\begin{array}{l}\text { Pulmonary diffusion } \\
\text { capacity for } \mathrm{O}_{2}(\mathrm{~L} / \mathrm{min})\end{array}$ & 979.5 & $948.9 \pm 392.1$ & $2.3 * \mathrm{Mb}^{.91}$ & $"$ \\
\hline
\end{tabular}

On the other hand it must be so that delivery of air to the lungs of giraffes is affected by their anatomy. The long neck increases dead space volume significantly as our data show (Table 1, Fig. 1A, B). We found that DS volume is $2.24 \mathrm{~L}$ in a $775 \mathrm{~kg}$ giraffe and is on average $2.9 \pm 0.5 \mathrm{~mL} \mathrm{~kg}^{-1}$ body mass. Robin et al. (1960) reported a volume of $1.6 \mathrm{~L}$ in a giraffe of unknown body mass, (Patterson et al., 1957) and (Patterson et al., 1965) reported volumes of 1.2, 2.3 and $2.5 \mathrm{~L}$ or $2.6 \mathrm{~mL} \mathrm{~kg}^{-1}$ in $\mathrm{ca} 500 \mathrm{~kg}$ giraffes and Hugh-Jones et al. (1978), a volume of $1.2 \mathrm{~L}$ in a $400 \mathrm{~kg}$ giraffe $\left(3.0 \mathrm{~mL} \mathrm{~kg}^{-1}\right)$. Dead space volume is not, however, as large as it would 
be if trachea length and diameter increased proportionately as they should if a normal resistance to airflow is to be maintained (Calder, 1981). In giraffes our data (Table 1) show that trachea length scales to the power 0.43 , whereas in mammals generally it scales at 0.27 (Tenney and Bartlett, 1967). The trachea is significantly narrower (range $2.3-4.8$, mean $3.9 \mathrm{~cm}$ ) than predicted, its diameter scales to the power 0.37 , and its diameter:length ratio decreases from 3.3 to 1.9 during growth. Its predicted diameter is $2.5-6.0 \mathrm{~cm}$ (mean $4.5 \mathrm{~cm})$, and its predicted scaling exponent is 0.39 (Tenney and Bartlett, 1967). All these findings support (Hugh-Jones et al., 1978) and (Langman et al., 1982) conclusions that the giraffe's trachea is unusually narrow.

A consequence of a large DS is that tidal volume must also be larger if minute ventilation is to be maintained. The TV we calculated of $10.5 \pm 0.5 \mathrm{~mL} \mathrm{~kg}^{-1}(8.1 \mathrm{~L} / \mathrm{breath})$ is different to the TV found by (Patterson et al., 1957) and (Patterson et al., 1965), who reported values of $2.7-$ 4.1 L/breath (5.4-8.2 mL kg${ }^{-1}$ ) for $500 \mathrm{~kg}$ animals. Our calculated value is, however, similar to that found by Langman et al. (1982) of $7.0 \pm 0.1 \mathrm{~L} /$ breath for $600 \mathrm{~kg}$ giraffes $\left(11.7 \mathrm{~mL} \mathrm{~kg}{ }^{-1}\right)$. These volumes are greater than those found in mammals generally which are $7.7 \mathrm{~mL} \mathrm{~kg}{ }^{-1}$ or $3.9 \mathrm{~L} / \mathrm{breath}$ for a $500 \mathrm{~kg}$ animal (Stahl, 1967). We found TV to be increased on average by $400 \mathrm{~mL}$ compared to similar sized mammals, and it increases hyperallometrically. In addition, as the relative volume of giraffe lungs decreases with increases in body mass, TV forms an increasingly large part of lung volume as giraffes grow. The main consequence of the high TV:VL ratio appears to be a reduction of IRV to the negligible amount of $c a 6 \%$ of lung volume (cf 16\% in mammals generally). If so, giraffes cannot increase tidal volume significantly by taking deeper breaths: Giraffes are obliged to increase ventilation volumes by increasing respiratory rate. TV could be increased by exhaling more air from ERV, but even if giraffes could achieve this, this mechanism is counterproductive. ERV is the major component of FRC. FRC acts as a reservoir for oxygen and carbon dioxide and damps oscillations in alveolar gas composition. Our calculations suggest that FRC increases in proportion to increases in body size in giraffes (Table 2) and if it does it may be because RV increases as elastic recoil of the lungs declines and the chest wall stiffens. The increase in FRC with size is associated with decreases in $\mathrm{RR}$, which is the ideal combination for optimizing gas exchange (Calder, 1981).

Despite the large DS and TV, ventilation rates are not significantly different to expected volumes. The rates we calculated $\left(V_{\mathrm{E}}=c a 100 \mathrm{~mL} / \mathrm{kg} \mathrm{min}{ }^{-1} ; V_{\mathrm{A}}=c a 75 \mathrm{~mL} \mathrm{~kg} \cdot \mathrm{min}^{-1}\right)$ are similar to those reported by (Patterson et al., 1957), (Patterson et al., 1965) and (Langman et al., 1982) but higher than the value found by Hugh-Jones et al. (1978). Patterson et al found $V_{\mathrm{E}}$ to be 61.3-179.5 $\mathrm{L} \mathrm{min}^{-1}\left(122.6 \mathrm{~mL} / \mathrm{kg} \mathrm{min}^{-1}\right)$, Langman et al $64.8 \pm 2.5 \mathrm{~L} \mathrm{~min}^{-1}\left(108 \mathrm{~mL} / \mathrm{kg} \mathrm{min}^{-1}\right)$, and Hugh-Jones et al $30 \mathrm{~L} / \mathrm{min}\left(75 \mathrm{~mL} / \mathrm{kg} \mathrm{min}^{-1}\right)$. In passing, these data confirm that allometric respiratory rates for mammals in general and giraffes are similar. The average resting RR that we calculated for the giraffes of the range of body masses in our sample was $10.1 \pm 1.5$ b.p.m (range 8.3 for the largest giraffe and 14.6 for the smallest). These values fall within the range of direct observations reported by (Robin et al., 1960), (Hugh-Jones et al., 1978), (Langman et al., 1982) and (Worthington et al., 1991), and our own direct observations.

As a result of the narrow trachea, trachea cross-sectional area increases less than increases in ventilation: its exponent is 0.65 and that of ventilation is $c a 0.8$ ([Table 1] and [Table 2]). The ratio of ventilation to cross-sectional area is thought to be constant for all species (Tenney and Bartlett, 1967), and has the benefit of preventing turbulent airflow and the detrimental effect that 
turbulence has on airflow resistance (Calder, 1981), but in giraffes this ideal appears to be compromised by the need to minimize the DS volume. Resistance to airflow is exacerbated by turbulence at high air flow velocities and turbulence restricts running speed (Schroter, 1977). Hugh-Jones et al. (1978) have estimated that at rest mean airflow velocity in a giraffe is $180 \mathrm{~cm} / \mathrm{s}$ (cf. $100 \mathrm{~cm} / \mathrm{s}$ in humans). They also calculated that turbulence will occur at a flow rate of $2500 \mathrm{~cm} / \mathrm{s}$ which is reached at a $V_{\mathrm{E}}$ of $42 \mathrm{~L} / \mathrm{min}$, a $V_{\mathrm{E}}$ found during moderate exercise in giraffes.

Another consequence of the narrow trachea is an altered respiratory pattern. There is no respiratory pause between inspiration and expiration, and inspiration time is prolonged ([Patterson et al., 1965] and [Hugh-Jones et al., 1978]). Inspiratory air flow velocity reaches a plateau soon after the start of inspiration and a long, flat inspiratory airflow pattern follows lasting 2-3 s. The expiratory pattern is similar except that airflow velocity is maximal at the end of expiration rather than at the beginning as it is during inspiration. This pattern confirms that the narrow trachea offers significant resistance to airflow and that expiration is passive and effected by the relatively large and numerous elastic fibres in the lungs (Robin et al., 1960). A possibility is that the high resistance is related to the anatomy of the larynx. However, this is not the case (Harrison, 1980) nor is it related to a delay in laryngeal opening during inspiration arising from the very long recurrent laryngeal nerves. These nerves in giraffes contain a higher percentage of fast conducting fibres than they do in, say, humans ([Harrison, 1980] and [Harrison, 1981]) presumably as an adaptation to their great length. Another possibility is that the respiratory pattern is a consequence of low lung compliance caused by the more numerous and coarser elastic fibres:giraffe lung compliance $\left(300 \mathrm{~mL} / \mathrm{cm} \mathrm{H}_{2} \mathrm{O}\right)$ is lower than that of cows $(400 \mathrm{~mL} / \mathrm{cm}$ $\mathrm{H}_{2} \mathrm{O}$; Patterson et al., 1965).

Overall we have concluded that the static lung volumes of giraffes are smaller than expected for an animal of their body mass and surmise that this is because of the shape of their skeletons. Their dead space volume and tidal volume are much greater than expected because of their long necks, despite significant narrowing of their trachea which has the advantage of limiting increases in dead space volume. The main consequences of a small lung volume and a long trachea appear to be a reduced inspiratory reserve volume and high resistance to airflow. These limit the capacity to increase tidal volume, and prolong the time it takes to inhale and exhale a single breath. Nevertheless minute and alveolar ventilation rate are the same as they are in similar sized mammals and the supply of oxygen to tissues is not compromised, although during exercise lung anatomy may limit the aerobic capacity of giraffes.

\section{Acknowledgements}

We thank the management and staff of the Bubye Valley Conservancy, Zimbabwe for their logistical support and sponsorship of this study. Additional funds were provided by the Don Craib Trust (JDS), from a personal research grant (JDS) and the University of Wyoming (GM). Technical field support was provided by Sybrand van Sittert, Carl-Heinz Moeller, Kenneth Manyangadze, Mark Brewer, Lauren Leathem, David Roberts, Kyle Piearse, Declan Gallagher, and Blake Wilelmi. 


\section{References}

Badlangana, N.L., Bhagwandin, A., Fuxe, K. and Manger, P.R. 2007. Distribution and morphology of putative catecholaminergic and serotonergic neurons in the medulla oblongata of a sub-adult giraffe, Giraffa camelopardalis, J. Chem. Neuroanat. 34, pp. 69-79.

Bush, M., Custer, R.S. and Whitla, J.C. 1980.Hematology and serum chemistry profiles for giraffes (Giraffa camelopardalis: variations with sex, age, and restraint, J. Zoo Anim. Med. 11, pp. $122-129$.

Calder, W.A. 1981. Scaling of physiological processes in homeothermic animals, Annu. Rev. Physiol. 43, pp. 301-322.

Calder, W.A. 1996. Size, Function, and Life History, Dover Publications, Inc., Mineola, New York.

Cobbold,T.S., 1854. On the anatomy of the giraffe (Camelopardalis giraffa, Linn.) Ann. Mag.Nat. Hist., Edinburgh. 1854:1-5, and republished in the Annals June, pp. 484-488.

Cobbold, T.S. 1860. Contributions to the anatomy of the giraffe, Proc. Zool. Soc. (London), pp. 99-105.

Dagg, A.I. and Foster, J.B. 1976.The giraffe: its biology, behaviour, and ecology, Van Nostrand Reinhold, New York.

Drevemo, S., Grootenhuis, J.G. and Karstad, L. 1974. Blood parameters in wild ruminants in Kenya, J. Wildlife Dis. 10, pp. 327-333.

Gehr, P., Mwangi, D.K., Ammann, A., Maloiy, G.M.O., Taylor, C.R. and Weibel, E.R. 1981. Design of the mammalian respiratory system. V. Scaling morphometric pulmonary diffusing capacity to body mass: wild and domestic mammals, Resp. Physiol. 44, pp. 61-86.

Hall-Martin, A.J. 1977. Giraffe weight estimation using dissected leg weight and body measurements, J. Wildlife Manage. 41, pp. 740-745.

Harris, Capt. Sir W.C. 1963. Wild Sports of Southern Africa. 5th Edition. Henry G Bohn, London. Facsimile reprint, C Strunk, Cape Town.

Harrison, D.F.N. 1980. Biomechanics of the Giraffe larynx and trachea, Acta Otolaryn. 89, pp. 258-264.

Harrison, D.F.N. 1981. Fibre size frequency in the recurrent laryngeal nerves of man and giraffe, Acta Otolaryn. 91, pp. 383-389.

Hawkey, C.M. 1975. Comparative Mammalian Haematology, William Heineman Medical Books Ltd, London. 
Hayssen, V. and R.C. Lacy, R.C. 1988. Basal metabolic rates in mammals: taxonomic differences in the allometry of BMR and body mass, Comp. Biochem. Physiol. A 81, pp. 741754.

Hoppeler, H. and Weibel, E.R. 1998. Limits for oxygen and substrate transport in mammals, $J$. Exp. Biol. 201, pp. 1051-1064.

Hugh-Jones, P., Barter, C.E., Hime, J.M. and Rusbridge, M.M. 1978. Dead space and tidal volume of the giraffe compared with some other mammals, Resp. Physiol. 35, pp. 53-58.

Joly, N. and Lavocat, A. 1846. Recherches historiques, zoologiques, anatomiques et palaeontologiques sur la giraffe, Mem. Soc. Sc. Nat. Strasbourg Vol. III, pp. 1-112.

Langman, V.A., Bamford, O.S. and Maloiy, G.M.O. 1982. Respiration and metabolism in the giraffe, Resp. Physiol. 50, pp. 141-152.

Lydekker, R. 1901.Giraffidae, Library of Natural History, Saalfield Publishing Company, London.

Mitchell, G. and Skinner, J.D. 2009. An allometric analysis of the giraffe cardiovascular system, Comp. Biochem. Physiol. A 154, pp. 523-529.

Murie, J. 1872. On the horns, viscera and muscles of the giraffe, with a record of the postmortem examination of two specimens killed by a fire, Ann. Mag. Nat. Hist. Edinburgh. Ser 4 Vol IX, pp. 177-195.

Nagy, K.A. 2005. Field metabolic rate and body size, J. Exp. Biol. 208, pp. 1621-1625.

Nakakuki, S. 1983. The bronchial ramification and lobular division of the giraffe lung, Anat. Anz. 154, pp. 313-317.

Patterson, J.L.Warren, J.V., Doyle, J.T., Gauer, O., Keen, E.N. and Goetz, R.H. 1957.

Circulation and respiration in the giraffe, J. Clin. Invest. 36, p. 919.

Patterson, J.L., Goetz, R.H., Doyle, J.T., Warren, J.V., Gauer, O.H., Detweiler, D.K., Said, S.I., Hoernicke, H., McGregor, M., Keen, E.N., Smith, M.H., Hardie, E.L., Reynolds, M., Flatt, W.P. and Waldo, D.R. 1965. Cardiorespiratory dynamics in the ox and giraffe, with comparative observations on man and other mammals, Ann. N.Y. Acad. Sci. 127, pp. 393-413.

Prothero, J. 1979. Heart weight as a function of body weight in mammals, Growth 43, pp. 139150.

Robin, E.D., Corson, J.M. and Dammin, G.J. 1960. The respiratory dead space of the giraffe, Nature 186, pp. 24-26.

Schmidt-Nielsen, K. 1997. Animal Physiology, Cambridge University Press 617. 
Schroter, R.C. 1977.Convective flows in mammalian lungs. In: L. Bolis, K. Schmidt-Nielsen and S. Maddrel, Editors, Comparative Physiology, Cambridge University Press.

Stahl, W.R. 1967. Scaling of respiratory variables in mammals, J. App. Physiol. 22, pp. 453-460.

Taylor, C.R., Maloiy, G.M.O., Weibel, E.R., Langman, V.A., Kamau, J.M.Z., Seeherman, H.J. and Heglund, N.C. 1980. Design of the mammalian respiratory system. III. Scaling maximum aerobic capacity to body mass: wild and domestic animals, Resp. Physiol. 44, pp. 25-37.

Taylor, C.R., Karas, R.H., Weibel, E.R. and Hoppeler, H. 1987. Adaptive variation in the mammalian respiratory system in relation to demand: II. Reaching the limits to oxygen flow, Resp. Physiol. 69, pp. 7-26.

Tenney, S.M. and Bartlett, D. 1967. Comparative quantitative morphology of the mammalian lung: trachea, Resp. Physiol. 3, pp. 130-135.

Tenney, S.M. and Remmers, J.E. 1963. Comparative quantitative morphology of the mammalian lung: diffusing area, Nature 197, pp. 54-56.

Van Schalkwyk, O.L., Skinner, J.D. and Mitchell, G. 2004. A comparison of the bone density and morphology of giraffe (Giraffa camelopardalis) and buffalo (Syncerus caffer) skeletons, $J$. Zool. (London). 264, pp. 307-315.

Van Sittert, S.J., Skinner, J.D., Mitchell, G., 2010. From fetus to adult - an allometric analysis of the giraffe vertebral column. J. Exp. Zool. 314B (6), 469-479..

Vosmaer, A. 1787. Description du Chameau-Leopard (Camelopardalis), P Meyers and P Warner, Amsterdam.

Weibel, E.R., Bacigalupe, L.D., Schmitt, B. and Hoppeler, H. 2004. Allometric scaling of maximal metabolic rate in mammals: muscle aerobic capacity as determinant factor, Resp. Physiol. Neurobi. 140, pp. 115-132.

Worthington, J., Young, I.S. and Altringham, J.D. 1991. The relationship between body mass and ventilation rate in mammals, J. Exp. Biol. 161, pp. 533-536. 